Jurnal Pengabdian kepada Masyarakat

\title{
Penerapan Teknologi Budidaya Tanaman Stroberi Di Desa Pangkalan Kabupaten Indramayu
}

\author{
Aa Setiawan ${ }^{1)}$, Yudhy Kurniawan ${ }^{2}$, Wardika $^{3}$ \\ ${ }^{1,2,3}$ Politeknik Negeri Indramayu, Jl. Raya Lohbener Lama No.8 Indramayu \\ *aasetiawan@polindra.ac.id
}

\begin{abstract}
Kata Kunci:
Abstrak Kondisi geografis Indramayu yang berada di dataran rendah bukan lahan

Stroberi, yang tepat untuk membudidayakan tanaman stroberi. Namun bukan tidak mungkin

Dataran tanaman ini dapat tumbuh dan berkembang dengan baik. Tujuan program pengabdian

Rendah,

Rekayasa

iklim. masyarakat ini adalah memberikan pengetahuan dan keterampilan pemuda Desa Pangkalan dalam membudidayakan tanaman stroberi dengan menerapkan teknologi rekayasa iklim. Kegiatan dalam program ini yaitu merakit alat, melakukan pengujian, pengambilan data dan pemantauan tanaman stroberi. Kegiatan ini berhasil dilaksanakan dengan baik yang diindikasikan dengan kemampuan alat untuk menurunkan temperatur ruang greenhouse sebesar $33,06{ }^{\circ} \mathrm{C}$, serta kelembaban sebesar 80-90\%. Dari pemantauan selama 12 hari didapatkan hasil adanya penambahan panjang stolon $21 \mathrm{~cm}$, jumlah batang sebanyak 3 buah, tinggi batang $8,5 \mathrm{~cm}$, serta daun sebanyak 15 helai. Untuk buah stroberi dari pemantauan selama 6 hari menunjukkan perubahan warna dari putih dan merah muda menjadi merah tua semua.
\end{abstract}

Keywords: Strawberries, Lowlands, Climate engineering. \begin{abstract}
Indramayu's geographical condition in the lowlands is not the right land to
cultivate strawberry plants. But it is not impossible that this plant can grow and develop well. The purpose of this community service program is to provide knowledge and skills of Pangkalan Village youth in cultivating strawberry plants by applying climate engineering technology. Activities in this program are assembling tools, testing, data retrieval and monitoring strawberry plants. This activity was successfully carried out properly indicated by the ability of the tool to lower the greenhouse room temperature by 33.06 OC, and humidity by 80-90\%. From monitoring for 12 days obtained the results of the addition of stolon length of $21 \mathrm{~cm}$, the number of stems as much as 3 pieces, the height of the stem $8.5 \mathrm{~cm}$, and the leaves as many as 15 strands. For strawberries from monitoring for 6 days showed discoloration from white and pink to all dark red.
\end{abstract}

\section{PENDAHULUAN}

Pangkalan merupakan salah satu desa di Kecamatan Losarang Kabupaten Indramayu dimana kegiatan kepemudaan yang ternaung dalam organisasi karang taruna Suta Jiwa memiliki kreatifitas yang cukup tinggi. Salah satu program yang dilakukan pengurus karang taruna untuk menciptakan kemandirian ekonomi pemuda adalah dengan mengadakan wirausaha bididaya tanaman hidroponik dan berhasil memenuhi kebutuhan pasar desa. Berangkat dari keberhasilan tersebut, terbesit ide untuk membudidayakan jenis buah yang tidak tumbuh di wilayah Indramayu yaitu stroberi. Kondisi geografis Indramayu yang berada di dataran rendah nampaknya bukan lahan yang tepat untuk membudidayakan tanaman stroberi. Namun bukan tidak mungkin tanaman ini dapat tumbuh dan berkembang dengan baik. Untuk mengatasi perbedaan iklim ini, maka dibuat suatu rekayasa iklim yang sesuai dengan kebutuhan tanaman stroberi. Untuk mengurangi 
paparan langsung teriknya sinar matahari yang menerpa tanaman stroberi, maka dibuatlah greenhouse yang diselubungi dengan paranet. Selain dapat menurunkan suhu dan meningkatkan kelembaban, greenhouse paranet juga dapat melindungi tanaman stroberi dari angin kencang, hujan, serangga, hama, dan ulat. Untuk lebih menurunkan suhu dan meningkatkan kelembaban, maka dibuatlah water cooling spray yang ditempatkan dalam greenhouse. Water cooling spray merupakan air yang didinginkan dalam box untuk kemudian disemprotkan ke ke dalam greenhouse dalam bentuk kabut. Proses penyemprotan bekerja secara otomatis berdasarkan kontrol kelembaban. Tujuan program pengabdian masyarakat ini adalah melakukan bimbingan teknis untuk meningkatkan pengetahuan dan keterampilan pemuda Desa Pangkalan menerapkan teknologi rekayasa iklim tanaman stroberi.

\section{METODOLOGI}

Dalam melaksanakan program pengabdian kepada masyarakat penulis melakukan beberapa tahapan sebagai berikut:

$\checkmark$ Tahap pertama Tim merakit komponen sistem refrigerasi dan water spray system dan pengujian alat

$\checkmark$ Tahap kedua Tim melakukan pengambilan data

$\checkmark$ Tahap ketiga Tim melakukan pemantauan tanaman stroberi

Alur pelaksanaan program pengabdian kepada masyarakat sebagai berikut:

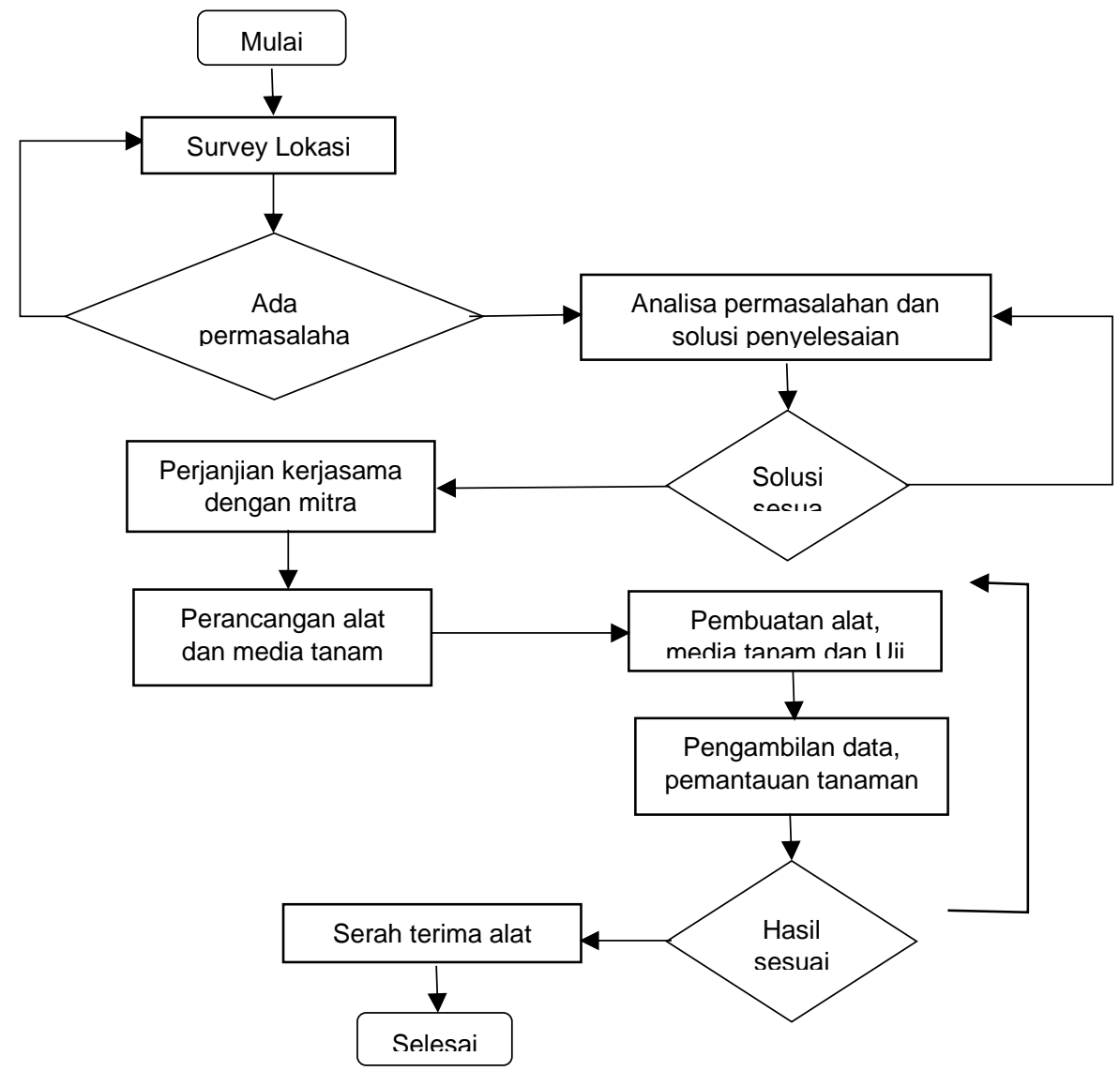

Gambar 1. Alur pelaksanaan PkM di Desa Pangkalan 


\section{HASIL DAN PEMBAHASAN}

3.1 Merakit komponen sistem refrigerasi dan water spray system dan pengujian alat

Pada pelaksanaan program PkM di Desa Pangkalan Kec. Losarang, Tim melakukan perancangan desain rekayasa iklim tanaman stroberi pada greenhouse yang akan di berikan kepada mitra, hasil perancangan dapat dilihat pada gambar 2 berikut:

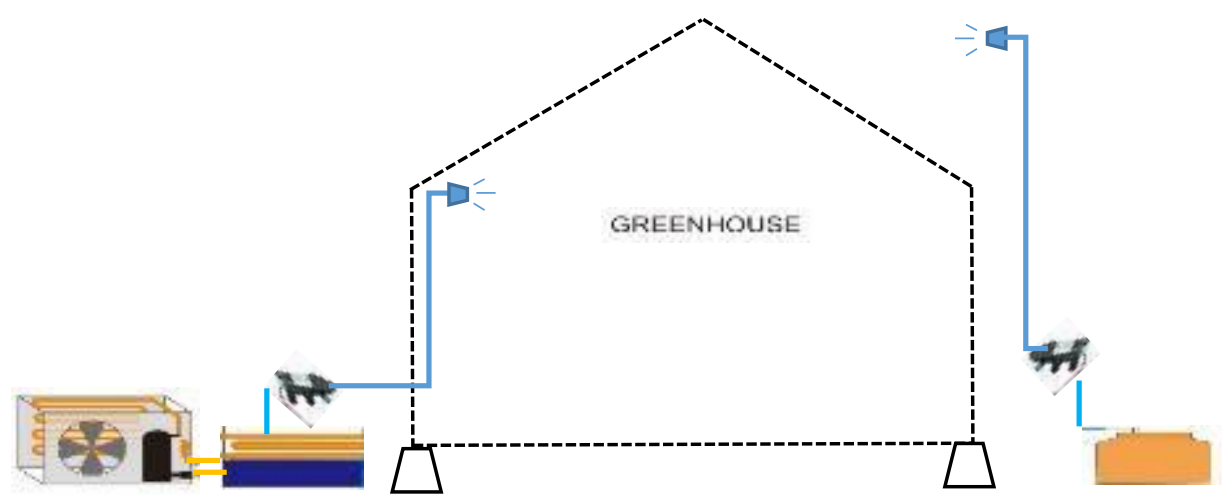

Gambar 2. Desain rekayasa iklim pada greenhouse

Keterangan :

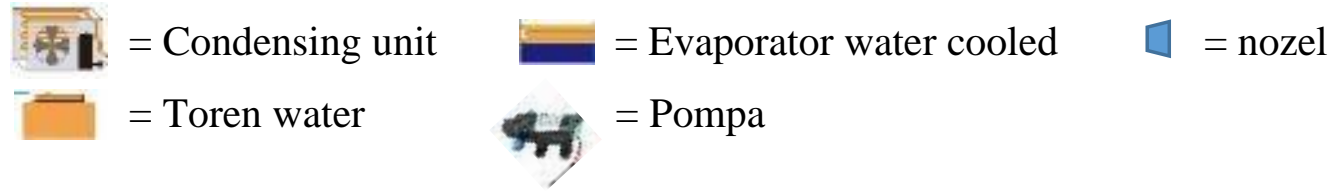

Tahapan awal yang dilakukan dalam pelaksanaan Pengabdian masyarakat ini adalah merakit komponen sistem refrigerasi yang akan digunakan untuk mendinginkan air dalam box sebagaimana ditunjukkan pada gambar 3. Komponen utama yang digunakan yaitu kompresor, kondensor, pipa kapiler, serta evaporator yang dicelupkan pada box berisi air. Perakitan ini dilakukan di lab. Teknik Pendingin dan Tata Udara Politeknik Negeri Indramayu.

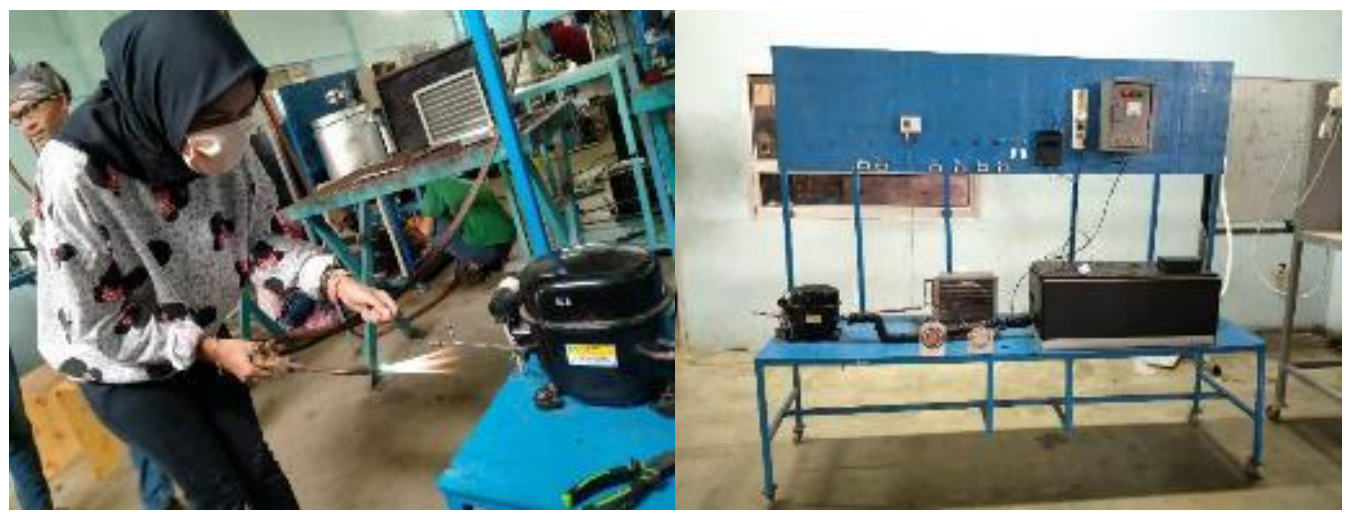

Gambar 3. Desain rekayasa iklim pada greenhouse

Dalam waktu yang bersamaan, gambar 4 menunjukkan pembuatan greenhouse menggunakan rangka baja ringan di lokasi mitra dengan dimensi 4 x 5 x 2,7 m. Setelah 
selesai, paranet $80 \%$ digunakan sebagai selubung greenhouse, serta dilakukan pemasangan selang dan nozel untuk spray air dingin yang ditunjukkan pada gambar 5 .

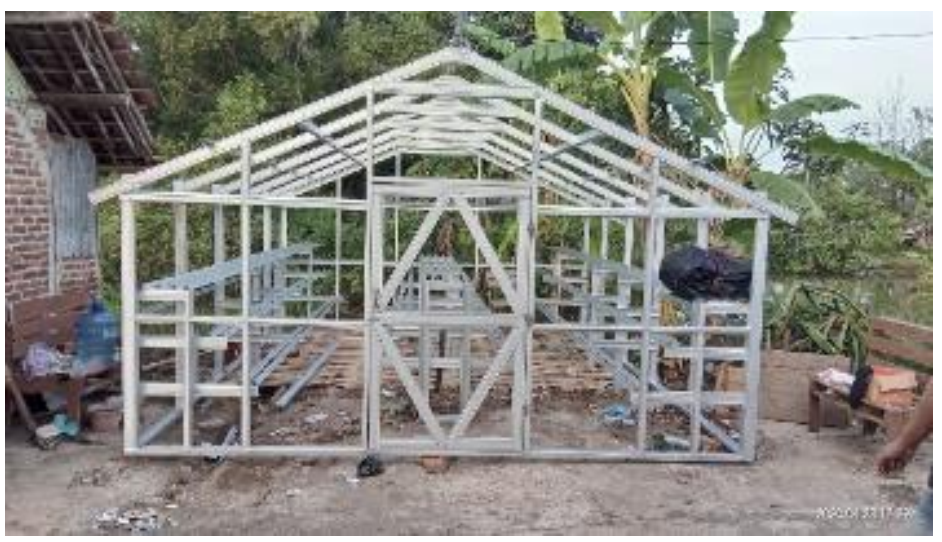

Gambar 4. Greenhouse Baja Ringan

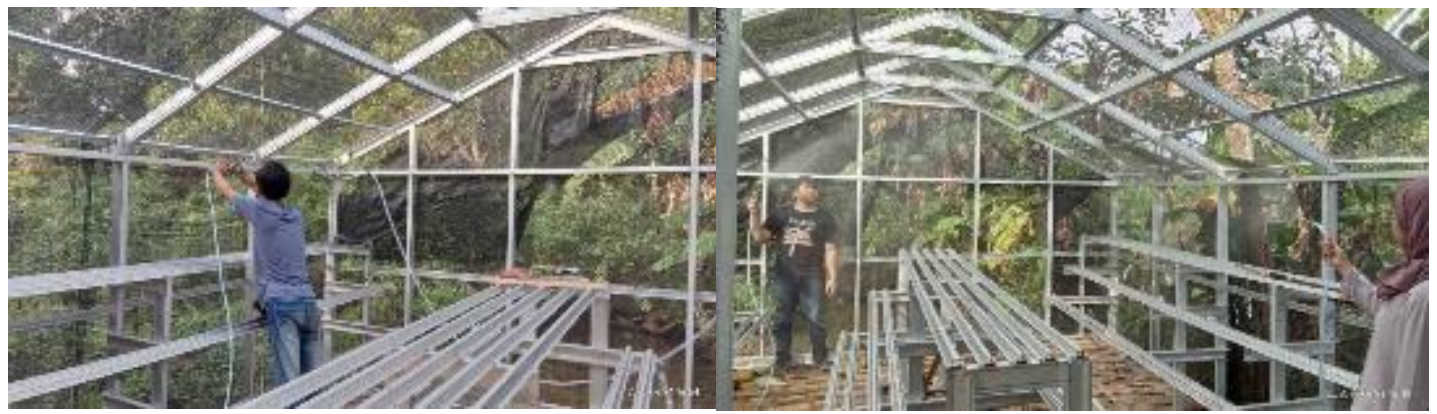

Gambar 5. Pemasangan selang dan nozel

Setelah greenhouse telah selesai dibuat, pada gambar 6 menunjukkan sistem refrigerasi dalam bentuk trainer didatangkan untuk kemudian dilakukan instalasi kontrol kelembaban dan perakitan selang spray agar sistem bekerja secara otomatis, dimana kelembaban dijaga dengan set poin 80 - 90\%. Setelah semua terpasang, dilakukan uji coba alat yang diawali dengan proses pendinginan air dalam box hingga mencapai temperatur yang direncanakan yaitu $17{ }^{\circ} \mathrm{C}$. Setelah temperatur tercapai, kontrol kelembaban mulai dijalankan. Apabila kelembaban dalam greenhouse di bawah $80 \%$, maka secara otomatis motor spray bekerja dan meningkatkan kelembaban dalam ruang greenhouse yang secara otomatis juga menurunkan temperatur. Spray air dingin akan berhenti jika kelembaban ruang greenhouse telah mencapai $90 \%$. Uji coba dilakukan dari pukul 08.00 sampai dengan 16.00 selama 3 hari. 


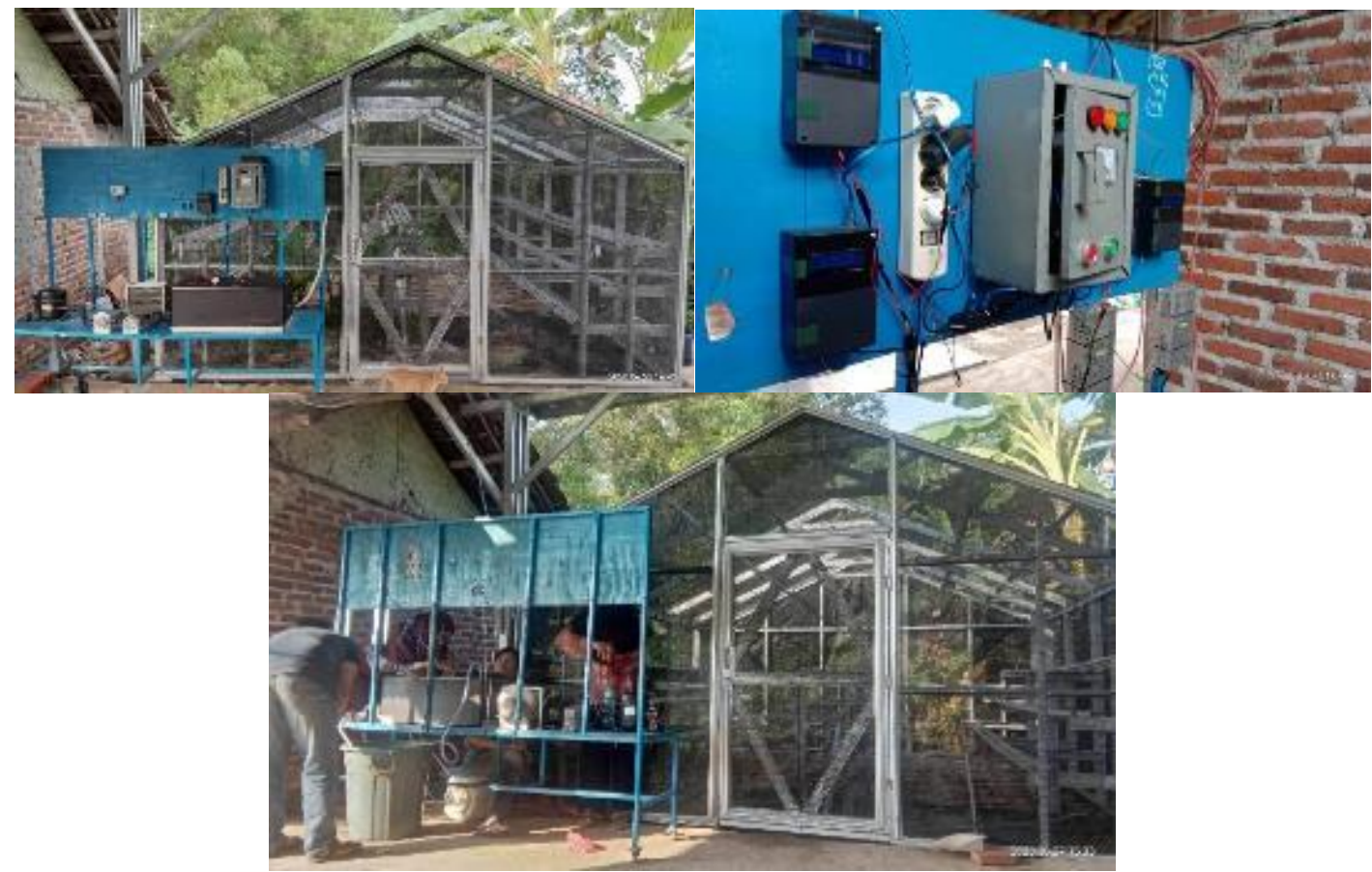

Gambar 6. Pembuatan kontrol dan pengujian sistem

\subsection{Pengambilan data}

Setelah proses pengujian alat telah selesai dilaksanakan, maka dilanjutkan dengan pengambilan data. Tabel 1 menunjukkan data yang diambil dari pukul 08.30 sampai dengan 15.28 dimana variabel yang diukur yaitu temperatur dan RH lingkungan, temperatur dan RH greenhouse, temperatur air kabin serta temperatur spray air dari nozel.

Tabel 1. Data hasil pengujian

\begin{tabular}{ccccccc}
\hline Waktu & $\begin{array}{c}\text { Temp. } \\
\text { Lingkungan }\end{array}$ & $\begin{array}{c}\text { Temp. } \\
\text { Greenhouse }\end{array}$ & $\begin{array}{c}\text { RH } \\
\text { Lingkungan }\end{array}$ & $\begin{array}{c}\text { RH } \\
\text { Greenhouse }\end{array}$ & $\begin{array}{c}\text { T air } \\
\text { kabin }\end{array}$ & $\begin{array}{c}\text { T air } \\
\text { spray }\end{array}$ \\
\hline 08.38 & 29,4 & 28,7 & 80 & 95 & 26,4 & \\
08.43 & 32,9 & 29,2 & 70 & 95 & 26,3 & \\
08.48 & 34,2 & 29,5 & 55 & 95 & 26,2 & \\
08.53 & 35,2 & 29,8 & 46 & 95 & 26 & \\
08.58 & 33,8 & 30,7 & 58 & 95 & 25,8 & \\
09.03 & 31 & 30 & 63 & 95 & 25,6 & \\
09.08 & 33,5 & 31,5 & 49 & 95 & 25,3 \\
09.13 & 34,5 & 32,3 & 45 & 94 & 25,1 \\
09.18 & 36 & 32,6 & 44 & 90 & 24,9 & \\
09.23 & 37,2 & 32,8 & 44 & 89 & 24,7 & \\
09.28 & 37,2 & 33 & 43 & 90 & 24,5 & \\
09.33 & 37,4 & 32,9 & 45 & 88 & 24,2 & \\
09.38 & 36,3 & 32,8 & 45 & 90 & 24 & \\
09.43 & 38,1 & 33,3 & 44 & 87 & 23,7 & \\
09.48 & 38,6 & 33,6 & 45 & 86 & 23,5 & \\
09.53 & 38,2 & 34,1 & 44 & 86 & 23,3 &
\end{tabular}




\begin{tabular}{|c|c|c|c|c|c|c|}
\hline 09.58 & 36 & 33,2 & 54 & 88 & 23,1 & \\
\hline 10.03 & 37,2 & 33,2 & 48 & 89 & 22,8 & \\
\hline 10.08 & 35 & 32,6 & 51 & 90 & 22,6 & \\
\hline 10.13 & 38,7 & 34 & 50 & 84 & 22,3 & \\
\hline 10.18 & 35,5 & 33,3 & 56 & 86 & 22 & \\
\hline 10.23 & 37,8 & 33,7 & 47 & 86 & 21,7 & \\
\hline 10.28 & 35,6 & 32,3 & 51 & 90 & 21,5 & \\
\hline 10.33 & 38,9 & 34,7 & 48 & 80 & 21,3 & 23,1 \\
\hline 10.38 & 39,4 & 34,6 & 45 & 85 & 22,1 & \\
\hline 10.43 & 38,4 & 34,5 & 44 & 85 & 22,8 & \\
\hline 10.48 & 38,2 & 34,6 & 48 & 80 & 22,5 & 24 \\
\hline 10.53 & 38,9 & 33,8 & 43 & 85 & 22,7 & 24,3 \\
\hline 10.58 & 39,6 & 34,7 & 47 & 83 & 22,4 & 24,1 \\
\hline 11.03 & 38 & 32,2 & 49 & 93 & 22,9 & \\
\hline 11.08 & 38 & 33,5 & 50 & 91 & 23,8 & \\
\hline 11.13 & 38,4 & 34 & 51 & 80 & 24 & 25,7 \\
\hline 11.18 & 38 & 32,7 & 55 & 94 & 23,5 & \\
\hline 11.23 & 38,5 & 34 & 50 & 88 & 24,1 & \\
\hline 11.28 & 38,9 & 34,4 & 45 & 85 & 24 & \\
\hline 11.33 & 39,1 & 34,4 & 50 & 82 & 23,8 & \\
\hline 11.38 & 38,8 & 34,1 & 47 & 84 & 23,5 & \\
\hline 11.43 & 39 & 34,4 & 48 & 80 & 23,1 & 25,4 \\
\hline 11.48 & 38,5 & 33,8 & 48 & 85 & 24,5 & \\
\hline 11.53 & 38,5 & 34,4 & 49 & 84 & 24,1 & \\
\hline 11.58 & 39,6 & 34,8 & 47 & 80 & 23,8 & 25,7 \\
\hline 12.03 & 38,4 & 33,3 & 46 & 85 & 24,5 & \\
\hline 12.08 & 39 & 33,4 & 45 & 87 & 24,5 & \\
\hline 12.13 & 38,9 & 34,2 & 44 & 80 & 24,7 & 26,1 \\
\hline 12.18 & 38,2 & 32,8 & 46 & 88 & 25 & \\
\hline 12.23 & 39 & 34 & 44 & 86 & 24,7 & \\
\hline 12.28 & 39,2 & 33,3 & 43 & 91 & 25,5 & \\
\hline 12.33 & 40,1 & 34,2 & 44 & 80 & 24,8 & 26,4 \\
\hline 12.38 & 38,4 & 33,7 & 45 & 80 & 24,5 & 26,1 \\
\hline 12.43 & 39,7 & 33,8 & 50 & 80 & 24,7 & 25,9 \\
\hline 12.48 & 40 & 33,1 & 42 & 80 & 24,4 & 25,8 \\
\hline 12.53 & 38,7 & 31,5 & 46 & 90 & 26,3 & \\
\hline 12.58 & 39,4 & 33,7 & 43 & 82 & 26 & \\
\hline 13.03 & 37,3 & 33,5 & 46 & 80 & 25,5 & 26,6 \\
\hline 13.08 & 39,2 & 33,6 & 45 & 80 & 26 & 27,8 \\
\hline 13.13 & 40,1 & 33,3 & 44 & 80 & 26,4 & 27,5 \\
\hline 13.18 & 35,5 & 32,6 & 61 & 90 & 26,8 & \\
\hline 13.23 & 36,8 & 33,1 & 50 & 80 & 26,9 & 27,3 \\
\hline 13.28 & 40 & 33,6 & 49 & 83 & 26,5 & \\
\hline 13.33 & 39,5 & 33,5 & 47 & 80 & 26,8 & 27,3 \\
\hline 13.38 & 39,8 & 33,1 & 47 & 80 & 27 & 27,7 \\
\hline
\end{tabular}




\begin{tabular}{|c|c|c|c|c|c|c|}
\hline 13.43 & 40,2 & 33,8 & 45 & 88 & 27,4 & \\
\hline 13.48 & 38,5 & 34 & 47 & 86 & 27,6 & \\
\hline 13.53 & 39,4 & 34,6 & 47 & 80 & 27,5 & 27,9 \\
\hline 13.58 & 39,5 & 33,8 & 61 & 88 & 27,4 & \\
\hline 14.03 & 38,7 & 33,4 & 66 & 89 & 27 & \\
\hline 14.08 & 39,3 & 33,8 & 62 & 88 & 26,7 & \\
\hline 14.13 & 40 & 33,8 & 63 & 85 & 26,5 & \\
\hline 14.18 & 39,9 & 33,6 & 68 & 89 & 26,3 & \\
\hline 14.23 & 35,9 & 32,7 & 66 & 90 & 26 & \\
\hline 14.28 & 39,4 & 33,3 & 68 & 90 & 25,8 & \\
\hline 14.33 & 35,3 & 32,5 & 70 & 90 & 25,6 & \\
\hline 14.38 & 39 & 33,3 & 67 & 89 & 25,3 & \\
\hline 14.43 & 38,2 & 33,3 & 67 & 89 & 24,9 & \\
\hline 14.48 & 36,6 & 33 & 68 & 89 & 24,6 & \\
\hline 14.53 & 34,1 & 32,4 & 70 & 93 & 24,4 & \\
\hline 14.58 & 36,7 & 32,7 & 68 & 91 & 24 & \\
\hline 15.03 & 33,6 & 32,4 & 69 & 89 & 23,7 & \\
\hline 15.08 & 35,3 & 33,2 & 71 & 90 & 23,5 & \\
\hline 15.13 & 32,6 & 31,8 & 72 & 91 & 23,2 & \\
\hline 15.18 & 35,5 & 32,5 & 67 & 88 & 23 & \\
\hline 15.23 & 34,4 & 33,2 & 68 & 87 & 22,7 & \\
\hline 15.28 & 33,9 & 32,5 & 67 & 88 & 22,3 & \\
\hline 15.33 & 33,4 & 32,6 & 69 & 88 & 21,8 & \\
\hline 15.38 & 33 & 32,1 & 68 & 92 & 21,5 & \\
\hline 15.43 & 32,8 & 32,3 & 68 & 91 & 21,3 & \\
\hline 15.48 & 33,1 & 32,3 & 67 & 91 & 21 & \\
\hline 15.53 & 33,1 & 32,4 & 69 & 92 & 20,8 & \\
\hline 15.58 & 32,8 & 32,3 & 68 & 92 & 20,5 & \\
\hline 16.03 & 32,7 & 32,1 & 69 & 92 & 20,2 & \\
\hline $\begin{array}{l}\text { Rata- } \\
\text { rata }\end{array}$ & 37,1122222 & 33,06333333 & $\mathbf{5 4 , 0 3 3 3 3 3 3}$ & 87,21111111 & 24,31556 & \\
\hline
\end{tabular}

Dari tabel 1 dapat dilihat bahwa rata-rata temperatur greenhouse yang mampu dicapai yaitu sebesar $33,06{ }^{0} \mathrm{C}$ masih jauh dari temperatur optimal yaitu antara $17-20$ ${ }^{0} \mathrm{C}$, namun masih dibawah rata-rata temperatur lingkungan yaitu sebesar $37{ }^{0} \mathrm{C}$. Dari tabel dapat dilihat juga water spray mulai berfungsi saat kelembaban ruang greenhouse dibawah $80 \%$ yaitu pada pukul 10.33 sapai dengan pukul 13.53 .

\subsection{Pemantauan perkembangan tanaman stroberi}

Gambar 7. Menunjukkan tanaman stroberi yang sudah ditempatkan pada rak dalam ruang greenhouse, tahap selanjutnya yaitu pengamatan terhadap perkembangan tanaman stroberi dari sisi panjang stolon, perkembangan daun dan buah stoberi. 


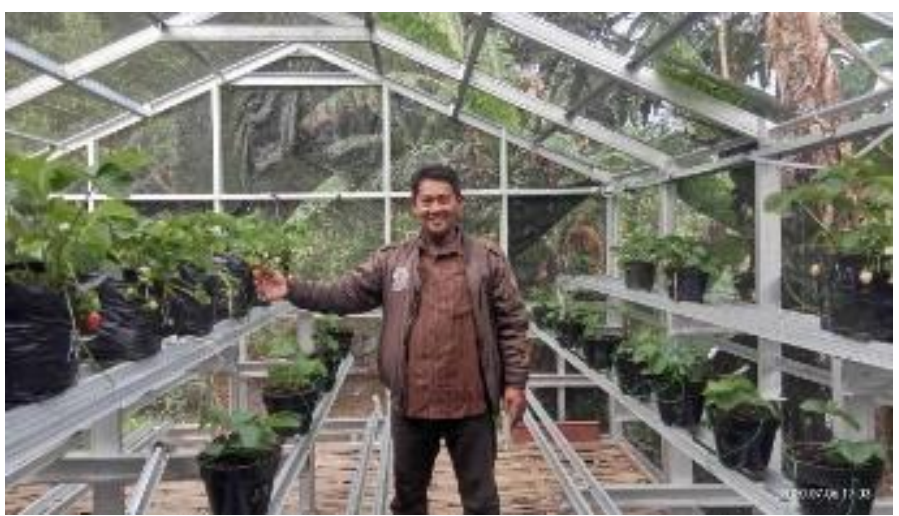

\section{Stolon}

Gambar 7. Tanaman stroberi dalam greenhouse

Stolon adalah perpanjangan tunas strawberry yang tumbuh horizontal sejajar dengan permukaan tanah (menjalar), yang merupakan organ perbanyakan vegetatif. Pengamatan panjang stolon dan tunas stroberi dilakukan selama 12 hari sejak berada dalam greenhouse.

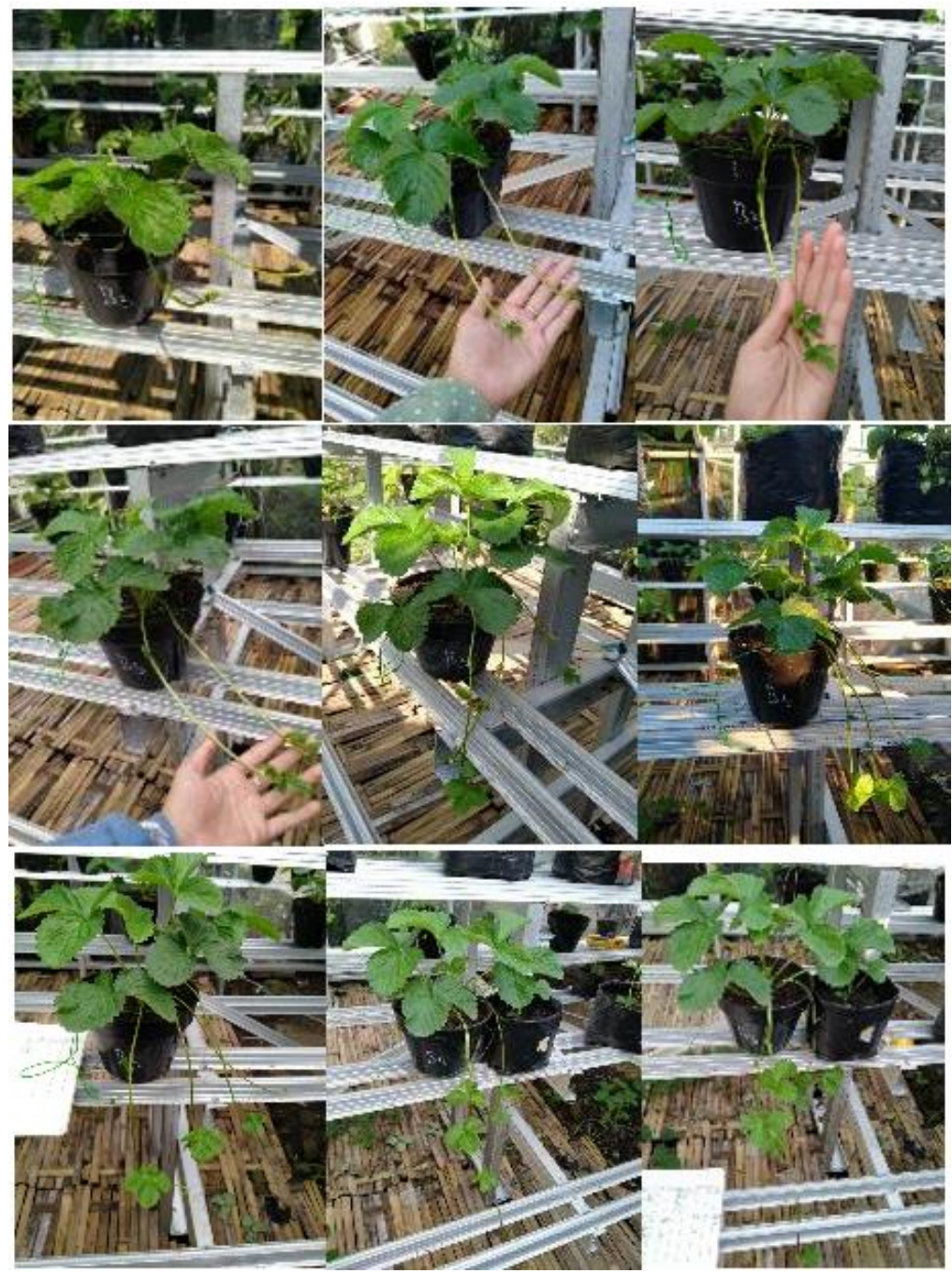

Gambar 8. Perkembangan stolon dan daun stroberi 
Dari gambar 8. Dapat dilihat perubahan panjang stolon dan tunas stroberi. Hari pertama dalam greenhouse stolon memiliki panjang $17 \mathrm{~cm}$ dan tunas yang belum memiliki daun. Setelah 12 hari memiliki panjang $38 \mathrm{~cm}$ serta tumbuhnya daun dan akar.

\section{Daun}

Dari gambar 8 juga dapat dilihat pada hari pertama stroberi memiliki 5 batang dengan tinggi rata-rata $5,5 \mathrm{~cm}$ serta jumlah daun 15 helai. Setelah 12 hari, nampak munculnya 3 batang baru. 5 batang yang awal telah memiliki tinggi rata-rata $14 \mathrm{~cm}$ serta secara keseluruhan memiliki 24 helai daun.

\section{Buah}

Pengamatan pada buah stroberi dilakukan selama 6 hari, dimana pada hari pertama nampak hanya 2 buah yang memiliki warna merah muda sebagaimana ditunjukkan pada gambar 9. Perubahan warna buah terjadi setiap hari dan pada hari ke 6 nampak semua buah telah berwarna merah tua dan siap untuk dipanen.

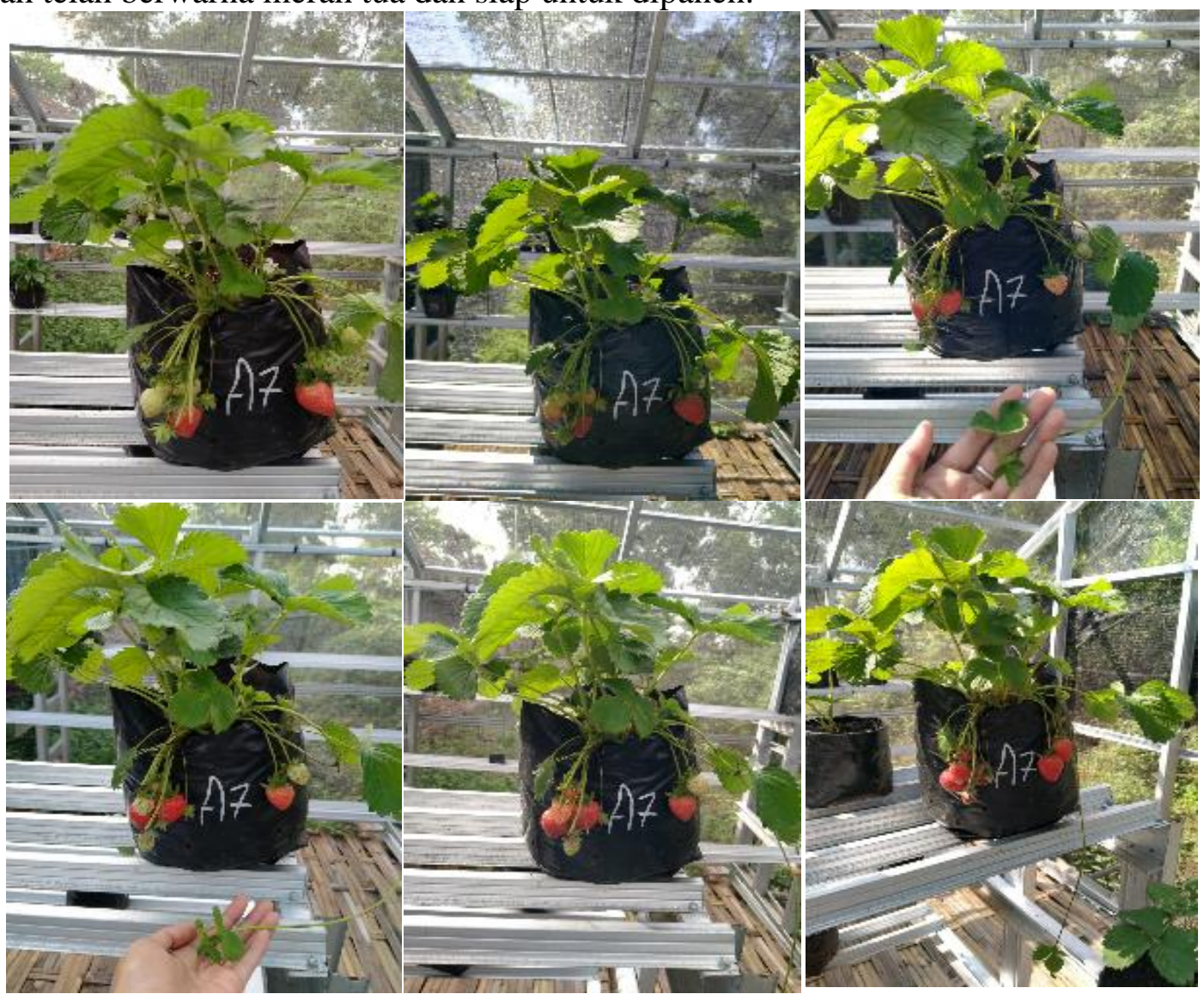

Gambar 9. Perkembangan buah stroberi 


\section{Pelaksanaan Serah terima}

Akhir dari kegiatan PkM adalah serah terima greenhouse stroberi yang dilakukan oleh ketua Tim PkM kepada mitra yang diwakili oleh Ketua dan jajaran pengurus karang taruna Desa Pangkalan sebagaimana ditunjukan pada gambar 9.

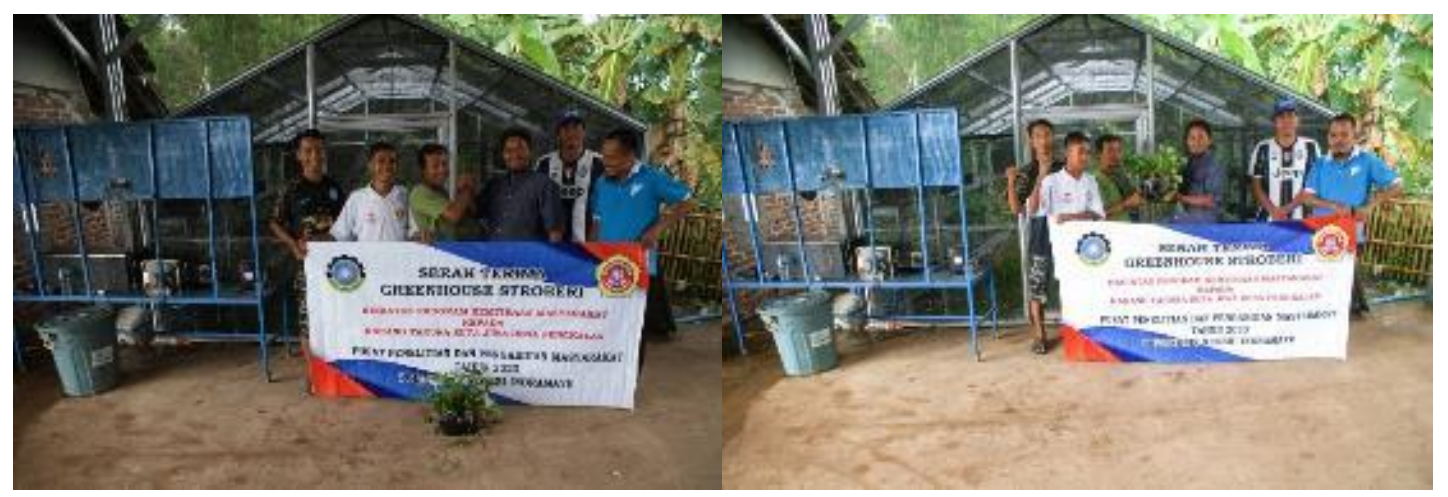

Gambar 9. Serah terima greenhouse stroberi

\section{KESIMPULAN}

Dari pelaksanaan program pengabdian kepada masyarakat untuk pemberdayaan pemuda Desa Pangkalan dalam membudidayakan tanaman stroberi dapat disimpulkan bahwa kegiatan telah terlaksana dengan baik. Dari sisi alat, meskipun temperatur dalam ruang greenhouse lebih tinggi yaitu $33,06{ }^{0} \mathrm{C}$ dibanding temperatur optimum tanaman stroberi antara $17-20{ }^{\circ} \mathrm{C}$, namun alat tersebut mampu mempertahankan kelembaban dalam ruang greenhouse yaitu sebesar 80-90\% sehingga tanaman stroberi masih bisa tumbuh dengan baik. Keberhasilan program kepada masyarakat juga ditunjukkan dengan tunbuh dan berkembangnya tanaman stroberi yang dibuktikan dengan adanya penambahan panjang stolon $21 \mathrm{~cm}$, penambahan jumlah batang sebanyak 3 buah, penambahan tinggi batang $8,5 \mathrm{~cm}$, serta penambahan daun sebanyak 15 helai dari pemantauan selama 12 hari. Untuk buah stroberi dari pemantauan selama 6 hari menunjukkan perubahan warna dari putih dan merah muda menjadi merah tua semua.

\section{Ucapan Terima kasih}

Tim Pelaksana program PkM mengucapkan terimakasih yang sebesar-besarnya kepada Politeknik Negeri Indramayu melalui Pusat Penelitian dan Pengabdian kepada Masyarakat telah memberikan pendanaan Internal tahun 2020 untuk pelaksanaan PkM sehingga berjalan dengan semestinya. Serta tidak lupa tim mengucapkan kepada mitra pengurus karang taruna Desa Pangkalan atas kerjasama yang baik sehingga pelaksanaan PkM dapat diselesaikan tepat waktu. 


\section{Daftar Pustaka}

ASHRAE Refrigeration Hand Book 2006. American Society of Heating, Refrigerating and air-conditioning Engineers, inc. Atlanta.

Setiawan Aa, AM Kartika, Wardika 2018. "The Effect of Climate Engineering on Strawberry Plant Growth in the Lowlands”. JTT (Jurnal Teknologi Terapan) vol. 4 No. 1. https://jurnal.polindra.ac.id/index.php/jtt/article/view/82

Alvin Febrian Ramadhan 2019. Pengaruh pemberian naungan terhadap pertumbuhan dan hasil pada tiga varietas tanaman stroberi. Jurnal produksi tanaman vol.7 No. 1. http://protan.studentjournal.ub.ac.id/index.php/protan/article/view/972

Budiman, Supriatin dan Saraswati, D. 2006. Berkebun Stroberi secara Komersial. Penebar Swadaya. Jakarta

Cahyono, Bambang. 2011. Sukses Budi Daya Stroberi di Pot dan Perkebunan. Yogyakarta: Lily Publisher.

Fatkhu Zaimah, Erma Prihastanti, Sri Haryanti, 2013. Pengaruh Waktu Pemotongan Stolon Terhadap Pertumbuhan Tanaman Strawberry. Buletin Anatomi dan Fisiologi Volume $X X I$, Nomor 2. https://ejournal.undip.ac.id/index.php/janafis/article/view/6272

(Ashrae, 2013). Handbook of Fundamental . USA: ASHRAE.

Gunawan, L. W. 2003. Stroberi. Penebar Swadaya. Jakarta. 81 p

https://pertanian.jogjakota.go.id/detail/index/12714 (13 November 2020) Budidaya Strawberry Di Dataran Rendah, diakses pada 21 Juli 2021

https://stf08.wordpress.com/teknik-budidayastrowbery/ (Mei 2008) diakses pada 21 Juli 2021 